\title{
Comparative Seed Morphology, Pharmacognostic, Phytochemical, and Antioxidant Potential of Memecylon L. Fruits
}

\author{
Memecylon L. Meyvelerinin Karşılaştırmalı Tohum Morfolojileri, \\ Farmakognostik, Fitokimyasal ve Antioksidan Potansiyelleri
}

\author{
(D) P. R. RAMYA SREE*, (D) J. E. THOPPIL \\ University of Calicut, Department of Botany, Cell and Molecular Biology Division, Kerala, India
}

\begin{abstract}
Objectives: Memecylon is the genus of the family Melastomataceae and their identification is somewhat difficult as a result of similarities in their intraspecies morphologies. Thus, identification of these species is much strenuous. The present study investigated the seed morphology, pharmacognostic, phytochemical, and antioxidant potential of Memecylon fruits.

Materials and Methods: The species Memecylon grande, Memecylon randerianum and Memecylon umbellatum were selected for this study. The surface morphology of seeds or fruits, pharmacognostic evaluation, and phytochemical analysis are effective methods for rectifying taxonomic difficulties in authentication process and it opens a platform for pharmaceutical analysis. The surface morphology was analyzed by scanning electron microscopy (SEM) and elemental compositions were revealed by using energy dispersive X-ray spectroscopy (EDX) and inductively coupled plasma-mass spectroscopy (ICP-MS). While evaluating the pharmacognostic property of the seeds, powder microscopic analysis was used, which focusesd on the functional purity of the fruit samples. 2,2-diphenyl-1-picrylhydrazyl, hydroxyl, nitric oxide and superoxide radical scavenging assays are carried out to determine the antioxidant potential of Memecylon fruits.

Results: The surface morphology of seeds had a distinct pattern of topography. SEM and EDX studies gave an insight on the elemental composition of the seeds. ICP-MS analysis showed the presence of biologically potent trace elements in the fruit samples. Quantitative estimation of secondary metabolites, such as alkaloids, terpenoids, flavonoids, and phenols, revealed that fruit extracts possess a significant amount of these phytoconstituents. The present study also reveals the antioxidant potential of Memecylon fruit extracts.

Conclusion: Powder microscopy, SEM, EDX and ICP-MS analyses provided knowledge about the functional purity and elemental composition of Memecylon fruits samples. The free radical scavenging assays showed that Memecylon fruits were natural antioxidant sources. Therefore, these findings can be effectively targeted toward the pharmacological utilization of Memecylon fruits.
\end{abstract}

Key words: Memecylon, SEM, EDX, powder microscopy, secondary metabolites, antioxidants

öz

Amaç: Memecylon, Melastomataceae ailesine ait bir cinstir ve türler arası morfolojilerin belirlenmesinin zor olması nedeniyle ayırt edilmeleri zordur. Bu nedenle, bu türlerin ayırt edilmeleri güçtür. Bu çalışmada Memecylon meyvelerinin karşılaştırmalı tohum morfolojileri, farmakognostik, fitokimyasal ve antioksidan potansiyelleri incelenmiștir.

Gereç ve Yöntemler: Memecylon grande, Memecylon randerianum ve Memecylon umbellatum türleri bu çalıșma için seçilmiștir. Tohumların veya meyvelerin yüzey morfolojileri, farmakognostik değerlendirmeleri ve fitokimyasal analizleri belgelendirme sürecinde taksonomik zorlukları rektifiye etmek için etkin yöntemlerdir. Yüzey morfolojileri taramalı elektron mikroskopisi (SEM) ile analiz edilmiștir ve elementel bileșimleri, enerji dağıtıcı X-ışını spektroskopisi (EDX) ve indüktif eşleşmiş plazma-kütle spektroskopisi (ICP-MS) ile açığa kavuşturulmuştur. Tohumların farmakognostik özelliklerini değerlendirirken, toz mikroskobik analizi kullanılmış ve meyve örneklerinin fonksiyonel saflığına odaklanılmıştır. 2,2-difenil-1-pikrilhidrazil, hidroksil, nitrik oksit ve süperoksit radikal süpürücü deneyleri Memecylon meyvelerinin antioksidan etkilerini belirlemek için gerçekleștirilmiştir. 
Bulgular: Tohumların yüzey morfolojileri belirgin topografik karakter göstermiştir. SEM ve EDX çalışmaları tohumların elementel bileşimi hakkında bilgi vermiştir. ICP-MS analizi meyve örneklerinde biyolojik olarak potent eser elementlerinin varlığını göstermiștir. Alkaloidler, terpenoidler, flavonoidler ve fenoller gibi sekonder metabolitlerin kantitatif oarak değerlendirilmesi meyve ekstraktlarının belirgin miktarda bu fitobileşenleri içerdiğini göstermiştir.

Sonuç: Toz mikroskopisi, SEM, EDX ve ICP-MS analizleri Memecylon meyve örneklerinin fonksiyonel saflık ve elementel bileşimleri hakkında bilgi vermiștir. Serbest radikal süpürücü yöntemleri Memecylon meyvelerinin doğal antioksidan kaynakları olduğunu göstermiștir. Bu nedenle, bu bulgular Memecylon meyvelerinin farmakolojik olarak kullanımlarının etkin olarak hedeflenmesini sağlayabilecektir.

Anahtar kelimeler: Memecylon, SEM, EDX, toz mikroskopisi, sekonder metabolitler, antioksidanlar

\section{INTRODUCTION}

Green technology and alternative eco-friendly products are brand new to several.' New lifestyle changes cause many perilous drawbacks, which opens a gateway for the search of new resolves. Thus, at present, the term "Green" has become much popular. The major area under "Green" consideration will be the field of traditional or herbal medicine. Herbal medicines are safe remedies for various human ailments, given their minimal side effects and low-cost treatments. Thus, there is wide acceptance of herbal medicinal system. The quality measurements of herbs are challengeable streams, where validations of herbs are more important than their usage. Adulterations are drawbacks in the field of herbal medicine, as they cause inconsistences in quality and safety of herbal preparations. This has opened a new approach to validate the quality assurance of herbs. The collection of plant materials, authentication of specimens, analysis, and formulation of drugs are the majorly value chain toward the discovery of safer natural drugs. Here in, an attempt was made to evaluate the pharmacognostic characters of the medicinally important genus Memecylon fruits.

Memecylon is the genus of the family Melastomataceae. There are 289 species of shrubs and trees widely distributed in tropical regions. In India, about 40 species were reported and 21 among them are endemic to the country. ${ }^{2}$ Memecylon species are difficult to identify due to the fact that their morphological similarities are some what confusing. Memecylon umbellatum and Memecylon randerianum are common species found in the Western Ghats. Another selected species for the present study is Memecylon grande, which is present in the Western Ghats and dry deciduous forests. Previous reports have revealed that these three species of Memecylon have potent medicinal activity. ${ }^{3,4}$ M. umbellatum possesses elliptic-lanceolate leaves with umbellate inflorescence and yellow berries. $M$. randerianum possesses ovate-oblong leaves and blueberries, while $M$. grande has ovate-lanceolate leaves with brownish blackberries.

Many systematic studies and new records are available on the genus Memecylon; however, evaluations of micromorphological characters are trivial. Scanning electron microscopy (SEM) analysis is the best way to analyze the surface features of the samples. In taxonomic identification, analysis of vegetative and reproductive characters through SEM is an effective method. ${ }^{5}$ The functional purity of plant samples is essential for pharmaceutical trails. In this present study, purity of sample was analyzed by powder microscopy, SEM-energy dispersive X-ray
(EDX), and inductively coupled plasma-mass spectrometry (ICP-MS) techniques. Powder microscopy acts as an effective tool for authentication plant materials. ${ }^{6}$ SEM-EDX and ICP-MS are effective analytical methods for analyzing metal nano- and micro-particles in food products, plant, or environmental. ${ }^{7}$ The backbone behind the performance of plants always hinge on the presence of bioactive metabolites. In majority of pharmaceutical studies, phytochemical analysis is a crucial step. Preliminary phytochemical analysis gives an insight on the phytochemical constituents present in plant extracts. It comprises qualitative and quantitative analysis. It provides valid information regarding the presence or absence of bioactive compounds in plant species. A plethora of biochemicals contribute to the specific bioactivity of plants, such as antimicrobial, antioxidant, and anticancer properties, among others. ${ }^{8}$ The present study also emphasizes the evaluation of the antioxidant potential of Memecylon fruit extracts. Antioxidants are free radical scavengers that neutralize oxidative stress induced by reactive oxygen species (ROS). Furthermore, ROS can disrupt normal cellular mechanisms and lead to severe pathological conditions and diseases, such as cancer, neurological disorders, atherosclerosis, hypertension, ischemia, and diabetes. ${ }^{9}$ The present study focused on the worth and utility of micromorphological characters and functional purity of fruit samples as an additional source of information in systematic studies of Memecylon.

\section{MATERIALS AND METHODS}

\section{Plant material}

Fruits of $M$. grande, M. randerianum, and $M$. umbellatum were chosen for the current study. Ripened mature fruits of the three species were collected from various parts of Kerala, India. The collected fruits were identified by Dr. A. K. Pradeep Assistant Professor, Angiosperm Taxonomy Division, Department of Botany, University of Calicut, Kerala.

\section{SEM analysis}

SEM analysis was performed using ZEISS Gemini SEM 300 machine. Samples were prepared on a carbon-coated copper grid. The technical features of Gemini SEM 300 are given below.

Gemini SEM 300 with resolutions: $0.6 \mathrm{~nm}$ a $30 \mathrm{kV}$ (STEM), $0.7 \mathrm{~nm}$ a $15 \mathrm{kv}, 1.2 \mathrm{~nm}$ a $1 \mathrm{kv}$, and $1.1 \mathrm{~nm}$ a $1 \mathrm{kV}$ TD. Inlens BSE resolution: $1.2 \mathrm{~nm}$ a $1 \mathrm{kV}$. Resolution in variable pressure mode (30 Pa): $1.4 \mathrm{~nm}$ a $3 \mathrm{kV}$ and $1.0 \mathrm{~nm}$ a $15 \mathrm{kv}$. Acceleration voltage: 0.02 - 30 kV. Probe current: $\mu 3$ pA-20 Na. Magnification: 122,000,000. 


\section{SEM-EDX analysis}

SEM-EDX analysis was done using Octane plus with Gemini $300 / E D S$. The active area selected for the present study was $30 \mathrm{~mm}^{2}$.

\section{Powder microscopy}

The fruit powder characteristics of Memecylon was analyzed under bright field microscope. The powder of the sample was treated with $4 \% \mathrm{KOH}$ and mounted in glycerine on clean slides and the powder characters were imaged using Nikon ECLIPSE E200 trinocular microscope attached with Zeiss AxioCam Erc5s digitalcamera. ICP-MS analysis

ICP-MS analysis was performed using Agilent 7800 ICPMS with Integrated Sample Introduction System (ISIS3) and SPS4 autosampler. It has astandard torch of $2.5 \mathrm{~mm}$-diameter injector, as well as Ni sampler and Ni skimmer cones.

\section{Preliminary quantitative phytochemical analysis}

\section{Alkaloid content}

The method of Shamsa et al. ${ }^{10}$ was followed for the determination of total alkaloid content of the selected plant material. In brief, $2 \mathrm{~N} \mathrm{HCl}$ solution was prepared and $1 \mathrm{mg}$ of the plant sample was dissolved in it and filtered. Phosphate buffer $(\mathrm{pH} 4.7)$ was prepared and $5 \mathrm{~mL}$ of it and $5 \mathrm{~mL} B C G$ solution was added and the mixture was shivered with 1, 2, 3, and $4 \mathrm{~mL}$ of chloroform. The chloroform layer containing alkaloids was separated. Caffeine was used as a standard. Absorbance of the solution was read at $470 \mathrm{~nm}$ against a blank. Alkaloid content of the sample was calculated and expressed as $\mathrm{mg}$ of caffeine equivalents.

\section{Flavonoid content}

Aluminium chloride colorimetric assay is a typical method for the determination of flavonoid content. ${ }^{11} 4 \mathrm{~mL}$ of distilled water was put in aflask and $1 \mathrm{~mL}$ of the extracts was added into it. $0.30 \mathrm{~mL}$ of $5 \% \mathrm{NaNO}_{2}$ and $0.3 \mathrm{~mL}$ of $10 \% \mathrm{AlCl}_{3}$ were mixed in the flask at five minutes intervals. Again, after five minutes incubation, $2 \mathrm{~mL}$ of $1 \mathrm{M} \mathrm{NaOH}$ was taken and the final volume of $10 \mathrm{~mL}$ was attained using distilled water. Finally, absorbance was read at $510 \mathrm{~nm}$. The total flavonoid present in the extract was calculated and expressed as $\mathrm{mg}$ quercetin equivalents (QE).

\section{Phenolic content}

Phenolic content of the sample was assayed by Folin Ciocalteu assay. ${ }^{12} 1 \mathrm{~mL}$ of the extracts was put in a $25 \mathrm{~mL}$ flask containing $9 \mathrm{~mL}$ of distilled water. $1 \mathrm{~mL}$ of Folin-Ciocalteu phenol reagent was mixed in the flask and shaken. At 5 minutes interval, 10 $\mathrm{mL}$ of $7 \% \mathrm{Na}_{2} \mathrm{CO}_{3}$ solution was added and the solution was kept for 90 minutes at room temperature. Absorbance was read at $550 \mathrm{~nm}$ against the reagent blank. Gallic acid was taken as the standard. The phenolic content was expressed as mg of Gallic acid equivalents.

\section{Terpenoid content}

Presence of terpenoid of the plant samples was estimated by the method of Ghorai et al. ${ }^{13}$ The reaction solution contains an aliquot of the extract and few drops of chloroform and $\mathrm{H}_{2} \mathrm{SO}_{4}$.
Absorbance is calculated at $538 \mathrm{~nm}$ against the blank. Linalool was taken as the standard. The terpenoid content of the extract was calculated and expressed as $\mathrm{mg}$ linalool equivalents (QE).

\section{Antioxidant activity}

The antioxidant potential of Memecylon fruits was documented on the basis of free radicals produced by various substrates, such as 2,2-diphenyl-1-(2,4,6-trinitrophenyl) hydrazyl (DPPH), $\mathrm{Fe}^{3+}$-ascorbate-EDTA- $\mathrm{H}_{2} \mathrm{O}_{2}$ system, sodium nitroprusside, and potassium ferricyanide.

\section{$D P P H$ radical scavenging assay}

The protocol of Chang et al. ${ }^{14}$ was followed for the determination of DPPH free radical scavenging activity of Memecylon fruit extract. DPPH is a free radical that reacts with antioxidant agents and gets reduced to DPPH-H. The pink colored DPPH turns yellow when scavenged by antioxidants. The color change indicates the scavenging latent of the antioxidant substances. Reference was selected as ascorbic acid $[10 \mathrm{mg} / \mathrm{mL}$ dimethyl sulfoxide (DMSO)]. Different volumes of the extracts [1.25-20 $\mu \mathrm{L}(12.5-200 \mu \mathrm{g} / \mathrm{mL})]$ from a stock concentration of $10 \mathrm{mg} / \mathrm{mL}$ was taken and made up to $20 \mu \mathrm{L}$ with DMSO and $1.48 \mathrm{~mL}$ of $\mathrm{DPPH}(0.1 \mathrm{mM})$ solution. The control was a test compound-free solution. A dark condition of 20 minutes was maintained for the reaction mixture at room temperature. Then, the scavenging potential was read at $517 \mathrm{~nm}$. Percentage inhibition of DPPH free radical by the extracts was calculated as follows:

$\%$ inhibition $=\frac{\text { control-test }}{\text { control }} \times 100$

\section{Hydroxyl radical scavenging activity}

Hydroxyl radical scavenging potential was analyzed according to the method described by Kunchandy and Rao. ${ }^{15}$ Different concentration of the samples $(125-2000 \mu \mathrm{g} / \mathrm{mL})$ from a stock solution of $10 \mathrm{mg} / \mathrm{mL}$ was mixed with $500 \mu \mathrm{L}$ reaction mixture [2-deoxy 2-ribose (2.8 mM), $\mathrm{FeCl}_{3}(100 \mu \mathrm{m})$, EDTA $(100 \mu \mathrm{m})$, $\mathrm{H}_{2} \mathrm{O}_{2}(1.0 \mathrm{mM})$, ascorbic acid $(100 \mu \mathrm{m})$ in $\mathrm{KH}_{2} \mathrm{PO}_{4}-\mathrm{KOH}$ buffer (2O $\mathrm{mM} \mathrm{pH} \mathrm{7.4)]} \mathrm{and} \mathrm{made} \mathrm{up} \mathrm{to} 1 \mathrm{~mL}$. The control was a solution devoid of the test material. The test sample tubes were kept at $37^{\circ} \mathrm{C}$ for 1 hour. $1 \mathrm{~mL}$ of $2.8 \%$ TCA and $1 \mathrm{~mL}$ of $1 \%$ aqueous TBA was mixed in the reaction tubes and allowed to stay for 15 minutes at $90^{\circ} \mathrm{C}$ for the color change. Absorbance was read at $532 \mathrm{~nm}$ against a blank. Gallic acid (10 mg/mL DMSO) was used as reference. Percentage inhibition of hydroxyl radical by the extracts was calculated as follows:

$\%$ inhibition $=\frac{\text { control-test }}{\text { control }} \times 100$

Nitric oxide radical scavenging activity

Determination of nitric oxide radical scavenging activity of Memecylon fruit extracts was performed according the method described by Kumaran and Karunakaran. ${ }^{16}$ Sodium nitroprusside $\left(5 \mathrm{~m} / \mathrm{mol}^{-1}\right.$ ) in phosphate buffered saline solution ( $\left.\mathrm{pH} 7.4\right)$ was added into various concentrations of extracts $(125-2000 \mu \mathrm{g} /$ $\mathrm{mL}$ ) from a stock solution. The reaction mixtures were then 
incubated at $25^{\circ} \mathrm{C}$ for 30 minutes. A control was also prepared and incubated accordingly. After 30 minutes incubation, $1.5 \mathrm{~mL}$ of the reaction mixtures were removed and $1.5 \mathrm{~mL}$ of Griess reagent ( $1 \%$ sulphanilamide, $2 \%$ phosphoric acid, and $0.1 \%$ $\mathrm{N}-1$-naphthylethylenediamine dihydrochloride) was added. Absorbance was read at $546 \mathrm{~nm}$. Gallic acid (10 mg/mL DMSO) was used as a reference compound. Percentage inhibition of nitric oxide radical by the extracts was calculated as follows:

$\%$ inhibition $=\frac{\text { control-test }}{\text { control }} \times 100$

\section{Superoxide radical scavenging activity}

Superoxide radical scavenging assay was performed according to the method described by Valentão et al. ${ }^{17} \mathrm{~A}$ concentration range of $(125-2000 \mu \mathrm{g} / \mathrm{mL})$ was taken from a stock solution (10 mg/mL). The reaction tube contained $0.05 \mathrm{~mL}$ of riboflavin solution ( $0.12 \mathrm{mM}), 0.2 \mathrm{~mL}$ of EDTA solution ( $0.1 \mathrm{M})$, and $0.1 \mathrm{~mL}$ of nitro blue tetrazolium solution (1.5 mM). $2.64 \mathrm{~mL}$ of phosphate buffer $(0.067 \mathrm{M})$ was added to the reaction mixture. Absorbance was read at $560 \mathrm{~nm}$ at two illumination times of 5 minutes and 30 minutes, respectively. Ascorbic acid (10 mg/mL DMSO) was used as reference. Percentage inhibition of superoxide radical by the extracts was calculated as follows:

$\%$ inhibition $=\frac{\text { control-test }}{\text { control }} \times 100$

\section{RESULTS AND DISCUSSION}

SEM is a high-resolution surface imaging technique that uses an electron beam with superior magnification power and depth of field precision. The seed capsule micromorphology and the entire seed morphology were studied by SEM analysis. The difference in electron emission in different areas provides the surface topography of the material. In this study, all the selected species showed distinct morphological patterns. Surface morphology is an important index in taxonomic identification. ${ }^{18}$ SEM analysis of Memecylon fruits is a novel report. In the case of M. grande, fruits show a colliculate pattern, with a seed capsule of $6.2 \mathrm{~mm}$, and the seed surface possesses a tuberculate pattern, with a width of $5.8 \mathrm{~mm}$ (Figure $1 \mathrm{A1}, \mathrm{B1}, \mathrm{C1}$, and D1). SEM analysis revealed that the seed capsule of $M$. randerianum a ruminate reticulate type pattern (Figure 1 A2, B2, C2, and D2). The width of the capsule was $4.2 \mathrm{~mm}$. The seed surface of $M$. randerianum was of a reticulate pattern, with a width of $3.5 \mathrm{~mm}$. M. umbellatum seed capsule possesses a smoothened pattern, with a width of $5.6 \mathrm{~mm}$, and its seed surface showed a wrinkled pattern, with a width of $3.81 \mathrm{~mm}$ (Figure $1 \mathrm{~A} 3, \mathrm{~B} 3, \mathrm{C} 3$, and D3). The characteristic surface morphology is a useful tool in the identification process.

EDX is an effective way of analyzing elemental compositions at tiny level. In this study, SEM was coupled with an energy dispersive system with an electron probe for X-ray microanalysis. The surfaces of the specimens were evaluated by SEM-EDX analysis and this gave a clear picture of the elemental composition of the test sample..$^{9}$ The elemental composition of $M$. grande fruits show that nitrogen content was $91 \%$, while that of other elements were as follows: Phosphorus $(3.10 \%)$, potassium $(1.53 \%)$, iron (1.41\%), magnesium $(0.87 \%)$, and sodium $(0.55 \%)$ (Figure 2). In the case of M. randerianum fruit, nitrogen was the prominent element, with $93 \%$ of the weight. Copper $(0.49 \%)$, cobalt $(0.90 \%)$, zinc $(0.09 \%)$, sodium $(0.03 \%)$, magnesium $(0.22 \%)$, phosphorus $(4.01 \%)$, potassium $(1.15 \%)$, and calcium $(0.09 \%)$ were the composition of other elements (Figure 3). M. umbellatum fruit also possesses an elevated amount of nitrogen (93\%) and the other elements were in trace amount: Phosphorus (3.4\%), potassium (1\%), copper (0.95\%), magnesium $(0.67 \%)$, cobalt $(0.34 \%)$, and iron $(0.22 \%)$ (Figure 4). This finding indicates that Memecylon fruits are reservoirs of essential elements and can be exploited in the pharmaceutical or nutritional field.

In Ayurveda, $90 \%$ of the preparations are plant-based, implying that the worthwhile usage of herbal medicines are promising remedies for diverse human diseases. In most Ayurvedic preparations, the powdered samples of plant parts are used. Therefore, the authenticity of the powdered sample is very important. Powder microscopy is a simple and easier method to analyze powdered samples and is an essential step in pharmacognostic evaluation of plant samples. Microscopic techniques examine the structural and cellular features of herbs, so as to determine their botanical origin. Microscopic

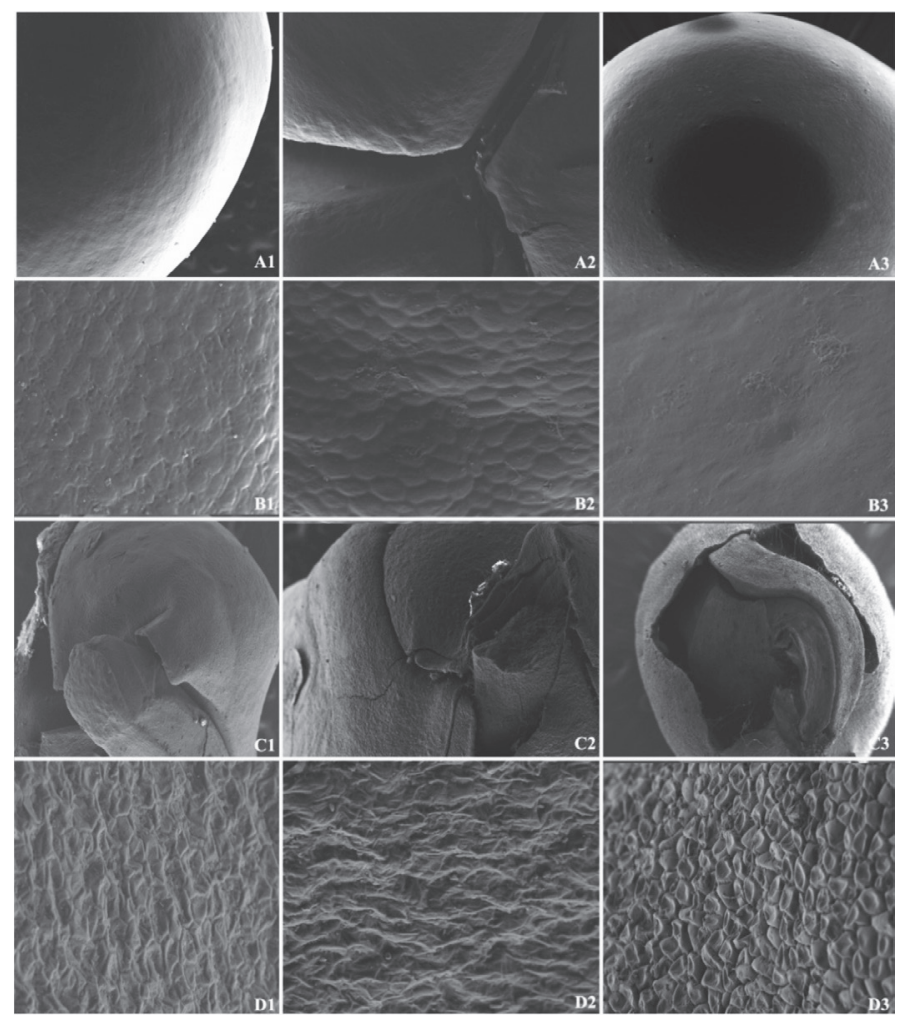

Figure 1. Scanning electron microscopic analysis of Memecylon fruits. A1) Memecylon grande seed capsule, B1) enlarged view, C1) seed surface, D1) Enlarged view. A2) Memecylon randerianum seed capsule, B2) enlarged view, C2) seed surface, D2 enlarged view. A3) Memecylon umbellatum seed capsule, B3) enlarged view, C3) seed surface, D3) enlarged view 
evaluation is now an indispensable tool for the identification of medicinal herbs and is among the important parameters in this modern time. ${ }^{20}$ Here in, the powdered samples of Memecylon fruits were characterized by their microscopic characters. The powdered M. grande fruits was brown in color, odorless, and slightly astringent (Figure 5). The characters found in the

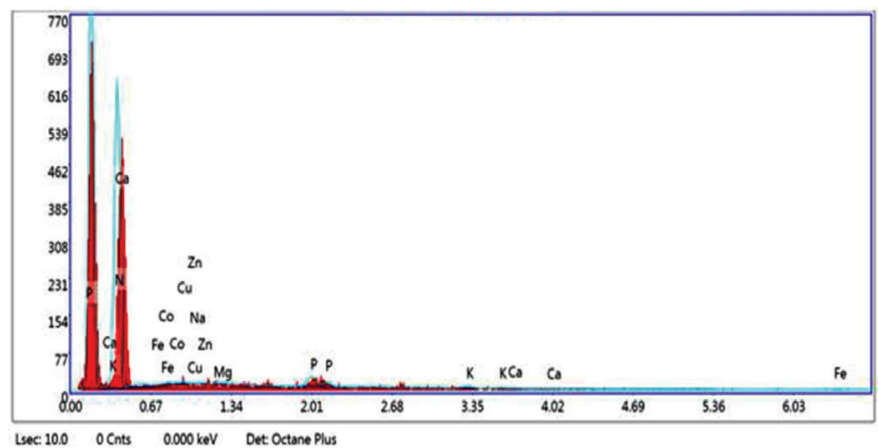

\begin{tabular}{|c|c|c|c|c|c|c|c|c|}
\hline Element & Weight $\%$ & Atomic \% & Net Int. & Error \% & Kratio & $z$ & A & $F$ \\
\hline NK & 93.07 & 97.14 & 352.96 & 5.86 & 0.7757 & 1.0137 & 0.8222 & 1.0000 \\
\hline Fel & 0.22 & 0.06 & 0.27 & 99.99 & 0.0009 & 0.7345 & 0.5352 & 1.0000 \\
\hline Col & 0.34 & 0.08 & 0.58 & 99.99 & 0.0017 & 0.7179 & 0.6777 & 1.0000 \\
\hline Cul & 0.95 & 0.22 & 247 & 87.46 & 0.0054 & 0.7059 & 0.8034 & 1.0000 \\
\hline $\mathrm{ZnL}$ & 0.11 & 0.02 & 0.30 & 99.99 & 0.0007 & 0.7054 & 0.8850 & 0.9996 \\
\hline NaK & 0.02 & 0.01 & 0.10 & 99.99 & 0.0001 & 0.8229 & 0.6657 & 1.0014 \\
\hline MgK & 0.67 & 0.41 & 4.65 & 75.71 & 0.0048 & 0.8943 & 0.7964 & 1.0024 \\
\hline PK & 3.40 & 1.61 & 17.74 & 29.96 & 0.0278 & 0.8363 & 0.9699 & 1.0066 \\
\hline KK & 1.00 & 0.37 & 278 & 75.64 & 0.0082 & 0.7962 & 1.058 & 1.0263 \\
\hline Cok & 0.22 & 0.08 & 0.47 & 99.99 & 0.0018 & 0.8074 & 1.0069 & 1.0336 \\
\hline
\end{tabular}

Figure 2. SEM-EDX analysis of Memecylon grande fruits SEM: Scanning electron microscopy, EDX: Energy dispersive X-ray

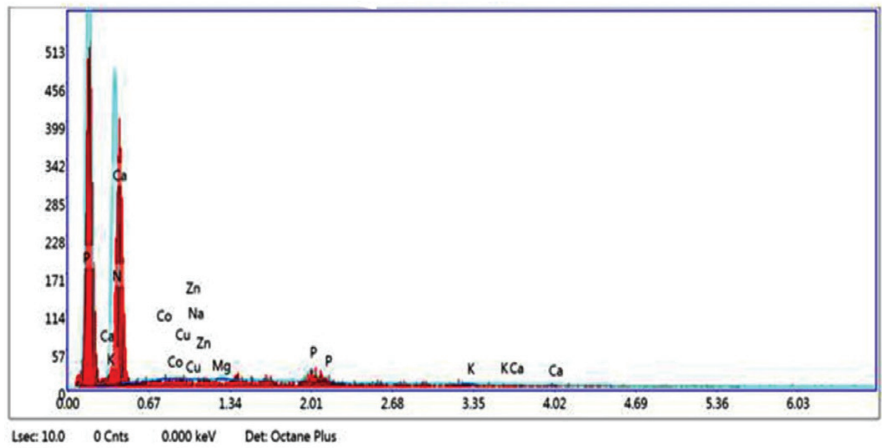

Element Weight \% Atomic\% Net lnt. Error $\%$ Kratio $Z$ A $\quad F$

\begin{tabular}{|lllllllll} 
NK & 93.02 & 97.14 & 265.63 & 6.41 & 0.7540 & 1.0139 & 0.7994 & 1.0000 \\
\hline CoL & 0.90 & 0.22 & 1.14 & 92.04 & 0.0043 & 0.7180 & 0.6575 & 1.0000 \\
\hline CUL & 0.49 & 0.11 & 0.95 & 99.99 & 0.0027 & 0.7060 & 0.7821 & 1.0000 \\
\hline ZnL & 0.09 & 0.02 & 0.20 & 99.99 & 0.0006 & 0.7055 & 0.8732 & 0.9995 \\
\hline NaK & 0.03 & 0.02 & 0.10 & 99.99 & 0.0002 & 0.8830 & 0.6427 & 1.0014 \\
\hline MgK & 0.22 & 0.13 & 1.17 & 82.21 & 0.0015 & 0.8944 & 0.7806 & 1.0026 \\
\hline PK & 4.01 & 1.89 & 16.70 & 30.68 & 0.0327 & 0.8365 & 0.9688 & 1.0065 \\
\hline KK & 1.15 & 0.43 & 2.58 & 77.90 & 0.0095 & 0.7963 & 1.0061 & 1.0249 \\
\hline CaK & 0.09 & 0.03 & 0.15 & 99.99 & 0.0007 & 0.8076 & 1.0071 & 1.0332 \\
\hline
\end{tabular}

Figure 3. SEM-EDX analysis of Memecylon randerianum fruits SEM: Scanning electron microscopy, EDX: Energy dispersive X-ray

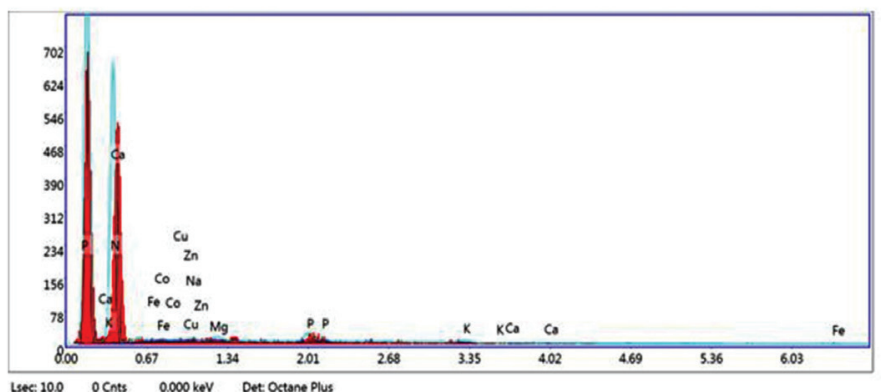

\begin{tabular}{|ccccccccc} 
Element & Weight \% & Atomic \% & Net Int. & Error \% & Kratio & $Z$ & A & F \\
\hline NK & 90.98 & 96.26 & 371.42 & 6.21 & 0.7249 & 1.0182 & 0.7826 & 1.0000 \\
\hline Fel & 1.41 & 0.37 & 1.99 & 77.04 & 0.0055 & 0.7379 & 0.5306 & 1.0000 \\
\hline Col & 0.63 & 0.16 & 1.18 & 99.99 & 0.0030 & 0.7212 & 0.6641 & 1.0000 \\
\hline CuL & 0.48 & 0.11 & 1.38 & 99.99 & 0.0027 & 0.7092 & 0.7867 & 1.0000 \\
\hline ZnL & 0.11 & 0.03 & 0.34 & 90.61 & 0.0007 & 0.7087 & 0.8740 & 0.9996 \\
\hline NaK & 0.55 & 0.36 & 3.02 & 95.61 & 0.0032 & 0.8870 & 0.6530 & 1.0013 \\
\hline MgK & 0.87 & 0.53 & 6.70 & 69.73 & 0.0061 & 0.8985 & 0.7839 & 1.0022 \\
\hline PK & 3.10 & 1.48 & 18.42 & 29.52 & 0.0253 & 0.8403 & 0.9655 & 1.0070 \\
\hline KK & 1.53 & 0.58 & 4.86 & 71.10 & 0.0126 & 0.8001 & 1.0055 & 1.0260 \\
\hline CaK & 0.35 & 0.13 & 0.86 & 90.39 & 0.0030 & 0.8114 & 1.0050 & 1.0326 \\
\hline
\end{tabular}

Figure 4. SEM-EDX analysis of Memecylon umbellatum fruits SEM: Scanning electron microscopy, EDX: Energy dispersive X-ray

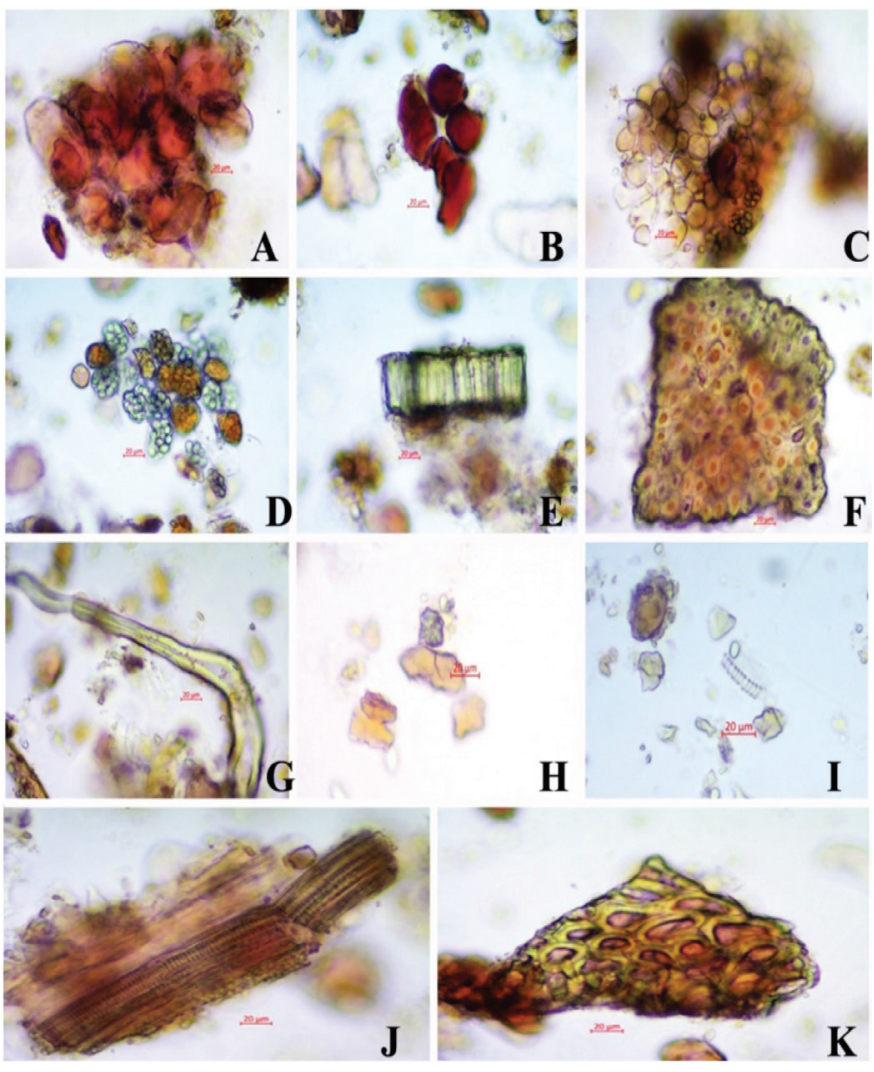

Figure 5. Powder microscopic analysis of Memecylon grande fruits. A, B) Epicarp cells; C, D) mesocarp parenchyma cells with starch grains; E) transversely cut testa; F) sclereidal fiber; G) rosette crystal; H) spira vessels; I) sclereids from endocarp; J) annular vessels; $K$ ) testa in surface view 
powders were epicarp cells, parenchyma cells with starch grains from mesocarp, stone cells from mesocarp, sclereids from endocarp, vessels with spiral and annular thickenings, and rosette crystals. In the case of $M$. randerianum fruits powder, it is brown-colored, odorless with a characteristic taste (Figure 6), and contains epicarp cells, mesocarp parenchyma cells, stone cells, sclereids from endocarp, tracheids, fiber bundles, and rosette crystals. The same brown colored powder was also seen for M. umbellatum fruits (Figure 7), which showed characteristics, such as epicarp cells, pitted parenchyma cells from mesocarp, stone cells, sclereids, spiral vessels, fibro-sclereids, and rosette crystals. These characters can be used to identify authenticated plant specimens in Ayurvedic preparations. Therefore,we can easily identify the botanical origin of the plant specimen and clearly distinguish the presence of adulterants or allied species. Microscopic evaluation of M. umbellatum leaves was done according to the method described by Killedar et al. ${ }^{6}$ and the presence of lignified xylem with well-defined xylem fibers, vessels, and parenchyma was found. The presence of phloecentric vascular bundles surrounded by endodermis and crystal sheath was also reported. The powder microscopic analysis confirmed that the botanical origins of the plant samples were pure and devoid of foreign particles. Therefore, this result can be used as a future reference for identification of Memecylon fruits.

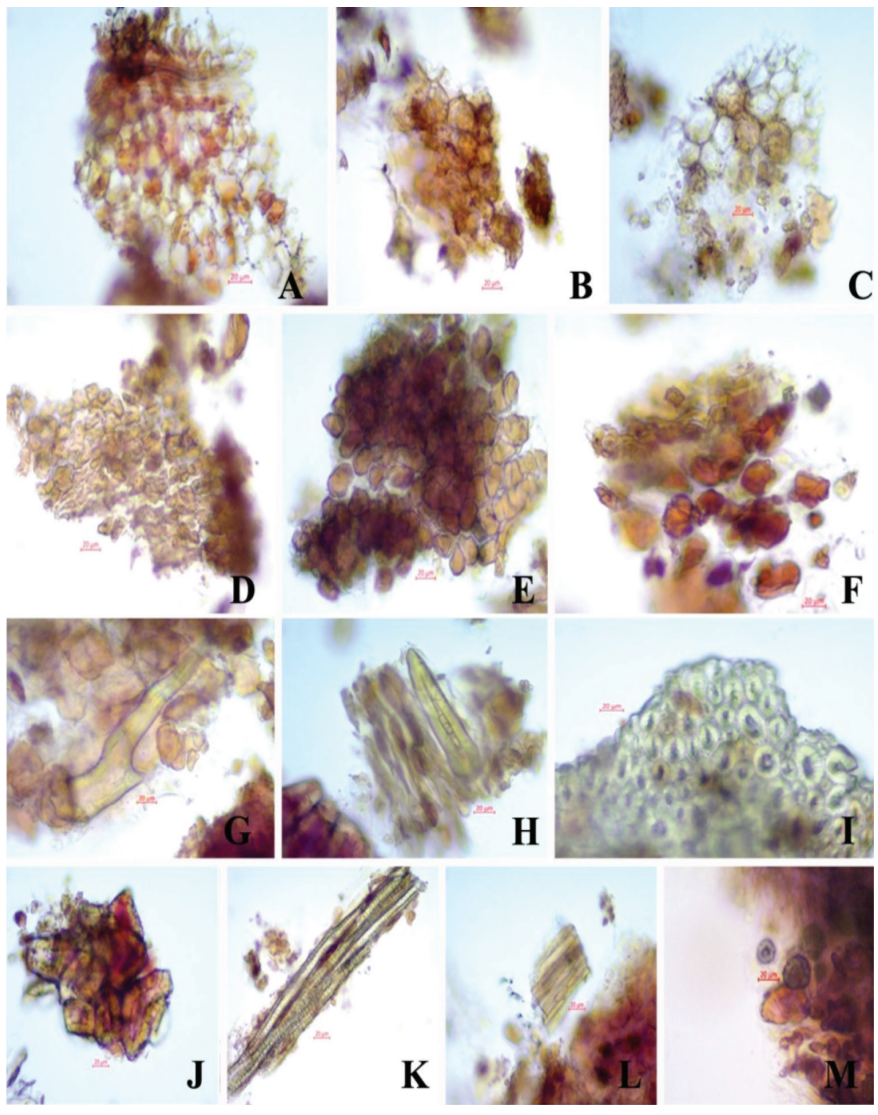

Figure 6. Powder microscopic analysis of Memecylon randerianum fruits. A) Mesocarp in sectional view; B) epicarp in surface view; C-F) mesocarp cells; G, H) sclereids; I, J) stone cells; K) tracheids; L) fiber bundles; M) rosette crystals
During the past decades, much attention have been focused on nutritional status. We had an insight into the profound effect of micro and macronutrients on biological processes that range from whole-organism performance to cellular function. According to the classification of trace elements, group I, which consists of carbon, hydrogen, oxygen, and nitrogen, are the key building blocks of carbohydrates, proteins, and lipids. Group II includes nutritionally important minerals, such as sodium, potassium, phosphorous, chloride, calcium, magnesium, and sulfur. Trace elements, such as like copper, iron, zinc, chromium, cobalt, iodine, molybdenum, and selenium, are found in group III. ${ }^{21}$ Copper is important in metabolism, mainly in the proper functioning of the enzymes and its deficiency can lead to hypochromic anemia, joint pain neutropenia, hypopigmentation of hair and skin, abnormal bone formation with skeletal fragility, and osteoporosis, among others. ${ }^{22}$ Another most important element is iron, which is a prime portion of the blood cells and its deficiency is called anemia. Anemia is the second vital cause of maternal mortality in India and $20 \%$ of the mortality is directly related to anemia, while another $50 \%$ is associated with other anemic side effects. In the case of zinc, it is crucial for normal spermatogenesis and maturation, development of thymus, epithelialization in wound healing, taste sensation, and secretion of pancreas and gastric enzymes. ${ }^{23}$

In addition to the SEM-EDX analysis, to substantiate the quality of the fruit samples in their elemental diversity, ICP-

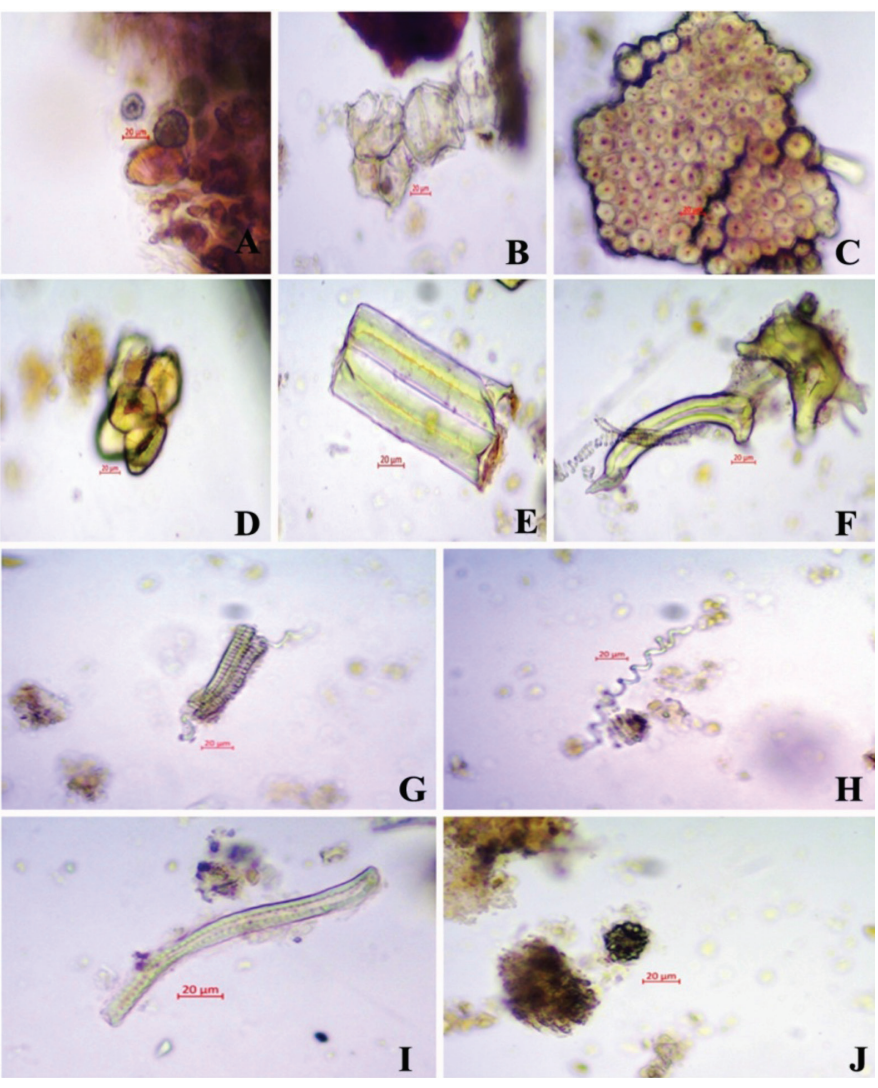

Figure 7. Powder microscopic analysis of Memecylon umbellatum fruits. A) Epicarp cells; B) pitted parenchyma cells of mesocarp; C) testa in surface view; D) stone cells; E, F) sclereids; G, H) spiral vessels; I) fibro-sclereid; J) rosette crystals 
MS analysis was performed. This technique gave details of the elements present in the sample in parts per million and determination ofthirteen elements, including aluminum, arsenic, cadmium, cobalt, strontium, selenium, chromium, copper, molybdenum, nickel, lead, barium, and manganese, were done. $M$. grande fruits show a promising concentration of majority of the elements, except for molybdenum and lead. Lead and molybdenum concentration were found to be higher in the case of $M$. randerianum fruit (Table 1). The standard reference concentrations of trace elements present in adult human blood samples are considered, considering that it is essential for the standardization of drugs. Most of the detected elements show vital biological functions. Some elements are functional parts of vitamins, cofactors of enzymes, oxidative phosphorylation, fatty acids, and cholesterol metabolism. Lead is considered as a non-essential elemental part of the human body, since it has no biological or health roles. In the case of chromium, it acts as a modulator of enzymes and as an activator of fatty acid and cholesterol metabolism. It can also enhance sugar metabolism. ${ }^{24}$ In the case of cobalt, it is the key factor of cobalamin (vitamin B12) and plays a vital role in the production of amino acids and neurotransmitters. Although the biological function of nickel is still somewhat unclear, nickel is found in higher concentration in RNA and is involved in protein structure. ${ }^{25}$ Therefore, the biological role of these trace elements is significant in the maintenance homeostasis and avoidance of free radical proliferation induction and various human ailments. ${ }^{26}$

Preliminary quantitative analysis of various phytochemicals was done following the proposed protocols. M. grande fruit was found to be rich in alkaloids, flavonoids, phenolics, and terpenoids (Table 2). All these phytoconstituents have a significant biological role. Liu ${ }^{27}$ proposes that phytochemicals are non-nutrient compounds that can reduce the risk of major noncommunicable chronic diseases and that are commonly found in fruits, vegetables, grains, and other plant foods. Alkaloids have a wide spectrum of pharmacological activity, ${ }^{28}$ which includes antifungal, antihyperglycemic, antityrosinase, antiglucosidase, antinociceptive, and antiinflammatory activities, among others. The efficiency of bioactive products in curing several diseases, such ashyperlipidemia, atherosclerosis, and hypertension, were studied by Liwa et al. ${ }^{29}$ Polyphenols and phenolic compounds are full sources of vascular vasodilators and are used to cure hypertension and cardiovascular diseases. Flavonoids possess anti-inflammatory, anticancerous, and antimutagenic activities, which have been previously reported. ${ }^{30}$ Tan et al. ${ }^{31}$ confirms that the progressive use of phytochemicals through diets is an effective method to cure diseases. Memecylon fruit extract showed a promising antioxidant activity in four different assays. All the fruit extracts show a dose gradient scavenging activity.

\section{Table 1. ICP-MS analysis of Memecylon fruits}

\begin{tabular}{|c|c|c|c|c|c|}
\hline \multirow{2}{*}{ Element } & \multirow{2}{*}{ Mass } & \multicolumn{3}{|c|}{ Concentration (ppm) } & \multirow{2}{*}{$\begin{array}{l}\text { Reference concentration of trace elements in adult } \\
\text { human blood }(\mu \mathrm{g} / \mathrm{L})^{20}\end{array}$} \\
\hline & & MGF & MRF & MUF & \\
\hline $\mathrm{Al}$ & 27 & 83135.864 & 41909.731 & 38739.426 & $2-8$ \\
\hline $\mathrm{Cr}$ & 52 & 10.223 & 5.923 & 4.016 & $<5$ \\
\hline $\mathrm{Mn}$ & 55 & 1790.173 & 786.657 & 272.022 & $8-12$ \\
\hline Co & 59 & 1.658 & 0.627 & 0.709 & $5-10$ \\
\hline $\mathrm{Ni}$ & 60 & 46.030 & 9.316 & 30.256 & $1-5$ \\
\hline $\mathrm{Cu}$ & 63 & 191.231 & 69.677 & 85.967 & $800-1100$ \\
\hline $\mathrm{Zn}$ & 66 & 320.408 & 119.412 & 118.666 & $6000-7000$ \\
\hline As & 75 & 1.620 & 1.048 & 0.958 & $2-20$ \\
\hline (As) & 77 & 19.861 & 5.952 & 5.418 & $2-20$ \\
\hline (As) & 78 & 25.097 & 9.117 & 8.453 & $2-20$ \\
\hline $\mathrm{Se}$ & 82 & 14.152 & 2.834 & 0.337 & $90-130$ \\
\hline $\mathrm{Sr}$ & 88 & 880.178 & 148.725 & 275.348 & $1.5-3.9$ \\
\hline Mo & 95 & 0.843 & 18.423 & 3.921 & $1-3$ \\
\hline $\mathrm{Cd}$ & 111 & 1.013 & 0.364 & 0.304 & $0.3-1.2$ \\
\hline $\mathrm{Ba}$ & 137 & 451.711 & 111.353 & 105.197 & $0.5-2.5$ \\
\hline$(\mathrm{Pb})$ & 206 & 24.184 & 58.300 & 17.053 & 50-150 \\
\hline$(\mathrm{Pb})$ & 207 & 24.904 & 59.807 & 17.365 & $50-150$ \\
\hline $\mathrm{Pb}$ & 208 & 24.558 & 63.138 & 17.170 & $50-150$ \\
\hline
\end{tabular}

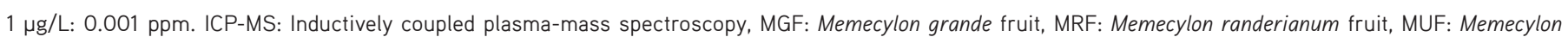
umbellatum fruit 
Among the extracts, $M$. grande fruit extract showed the highest free radical scavenging activity in all the assays, followed by $M$. umbellatum and $M$. randerianum fruit extracts (Figure 8-11). $M$. grande fruit extracts showed that highest nitric oxide scavenging activity $(76.85 \pm 0.08)$ and the least hydroxyl radical scavenging activity $(61.69 \pm 0.56)$. M. randerianum fruit showed the least hydroxyl radical scavenging activity $(46.16 \pm 0.17)$. Based on the four assays performed, the most effective antioxidant extracts was that of $M$. grande fruit, with an $I_{50}$ of $83.9195 \pm 0.14$. This was followed by $M$. umbellatum, with an $\mathrm{IC}_{50}$ of $91.1031 \pm 0.12$, and $M$. randerianum, with an $\mathrm{IC}_{50}$ of $104.178 \pm 0.13$ (Table 3 ). Antioxidant capacity and total phenolic content are directly related. ${ }^{32}$ The quantitative phytochemical analysis justifies the high performance of these species in the antioxidant assays. M. grande fruit extract $(370.28 \pm 8.36)$ possessed the highest

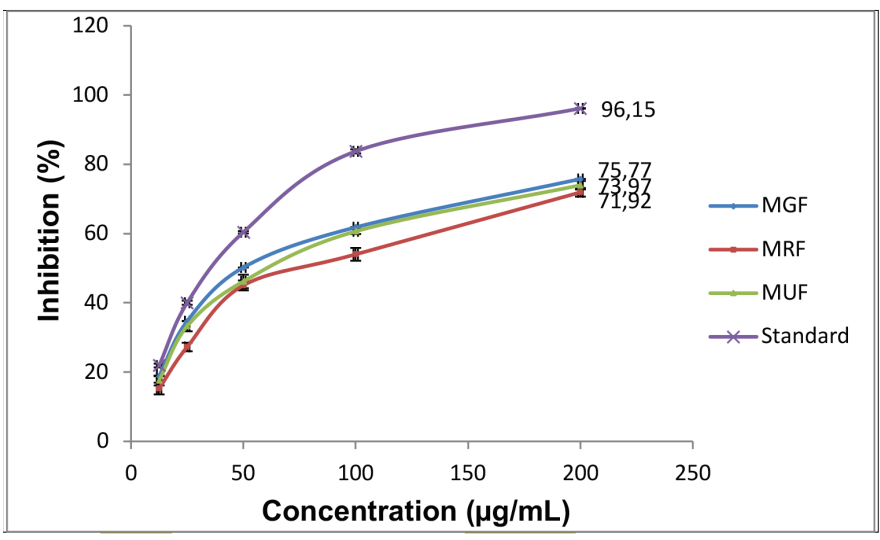

Figure 8. In vitro DPPH scavenging activity of Memecylon fruits

DPPH: 2,2-diphenyl-1-(2,4,6-trinitrophenyl) hydrazyl, MGF: Memecylon grande fruit, MRF: Memecylon randerianum fruit, MUF: Memecylon umbellatum fruit phenolic content, making it a good candidate pharmaceutical agent.

\section{Study limitations}

The detailed phytochemical characterization and compound isolation can be more satisfactory in pharmaceutical applications. The present findings are useful in the pharmaceutical field, since the botanical purification of plants is the prime step in natural drug formulation. These results can be used as a future reference for the evaluation of Memecylon fruits.

\section{CONCLUSION}

Seed surface characteristics are used as diagnostic tools in taxonomic studies. Powder microscopy, SEM-EDX, and ICP-MS analysis have provided knowledge about the functional purity and elemental composition of Memecylon fruits samples. The

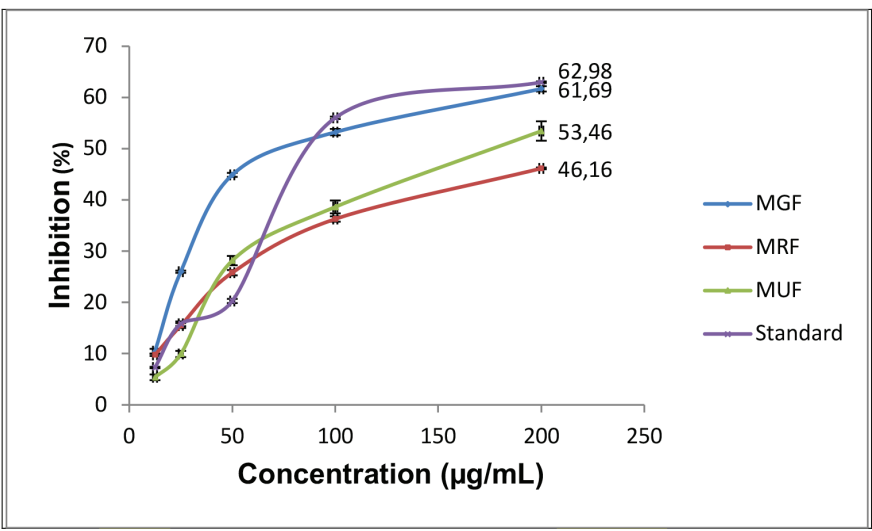

Figure 9. In vitro hydroxyl radical scavenging activity of Memecylon fruits MGF: Memecylon grande fruit, MRF: Memecylon randerianum fruit, MUF: Memecylon umbellatum fruit

Table 2. Preliminary quantitative phytochemical analysis of Memecylon fruits

\begin{tabular}{lllll} 
Plants & $\begin{array}{l}\text { Alkaloids } \\
(\mathrm{mg} \text { caffeine/g DW }) \pm \mathrm{SE}\end{array}$ & $\begin{array}{l}\text { Flavonoids } \\
(\mathrm{mg} \text { quercetin/g DW }) \pm \mathrm{SE}\end{array}$ & $\begin{array}{l}\text { Phenolics } \\
(\mathrm{mg} \mathrm{GAE} / \mathrm{g} \text { DW }) \pm \text { SE }\end{array}$ & $\begin{array}{l}\text { Terpenoids } \\
(\mathrm{mg} \text { linalool/g DW) } \pm \text { SE }\end{array}$ \\
\hline MGF & $52.16 \pm 3.23^{\mathrm{d}}$ & $91.77 \pm 2.65^{\mathrm{c}}$ & $370.28 \pm 8.36^{\mathrm{d}}$ & $378.21 \pm 19.02^{\mathrm{c}}$ \\
\hline MRF & $32.17 \pm 1.41^{\mathrm{a}}$ & $21.40 \pm 2.72^{\mathrm{b}}$ & $276.06 \pm 14.12^{\mathrm{c}}$ & $355.03 \pm 57.31^{\mathrm{c}}$ \\
\hline MUF & $36.47 \pm 0.66^{\mathrm{ab}}$ & $57.57 \pm 4.40^{\mathrm{b}}$ & $60.83 \pm 5.70^{\mathrm{a}}$ & $127.5 \pm 10.50^{\mathrm{a}}$
\end{tabular}

Means within a column followed by the same letters are not significantly different at $p<0.05$, as determined by Duncan's multiple range test.

SE: Standard error, DW: Dry weight, GAE: Gallic acid equalent, MGF: Memecylon grande fruit, MRF: Memecylon randerianum fruit, MUF: Memecylon umbellatum fruit

Table 3. Effect of methanol extracts of Memecylon fruits in different antioxidant assays

$\mathrm{IC}_{50}$ values $(\mu \mathrm{g} / \mathrm{mL})$

\begin{tabular}{lllll}
\hline Plants & $\begin{array}{l}\text { DPPH radical scavenging } \\
\text { assay }\end{array}$ & $\begin{array}{l}\text { Hydroxyl radical scavenging } \\
\text { assay }\end{array}$ & $\begin{array}{l}\text { Nitric oxide radical } \\
\text { scavenging assay }\end{array}$ & $\begin{array}{l}\text { Super oxide radical scavenging } \\
\text { assay }\end{array}$ \\
\hline Standard & $48.8412 \pm 1.5^{\mathrm{a}}$ & $1347.51 \pm 0.27^{\mathrm{b}}$ & $346.207 \pm 0.01^{\mathrm{a}}$ & $238.357 \pm 0.03^{\mathrm{a}}$ \\
\hline MGF & $83.9195 \pm 0.14^{\mathrm{b}}$ & $1231 \pm 0.48^{\mathrm{a}}$ & $696.733 \pm 0.06^{\mathrm{b}}$ & $698.991 \pm 0.03^{\mathrm{b}}$ \\
\hline MRF & $104.178 \pm 0.13^{\mathrm{d}}$ & $2029.57 \pm 0.14^{\mathrm{e}}$ & $1081.61 \pm 0.01^{\mathrm{d}}$ & $311.24 \pm 0.02^{\mathrm{e}}$ \\
\hline MUF & $91.1031 \pm 0.12^{\mathrm{c}}$ & $1696.73 \pm 0.05^{\mathrm{c}}$ & $916.988 \pm 0.04^{\mathrm{c}}$ & $1129.34 \pm 0.01^{\mathrm{c}}$ \\
\hline
\end{tabular}

Means within a column followed by the same letters are not significantly different at $\mathrm{p}<0.05$ as determined by Duncan's multiple range test. DPPH: 2,2-diphenyl-1-

(2,4,6-trinitrophenyl) hydrazyl, Correct it as MGF: Memecylon grande fruit, MRF: Memecylon randerianum fruit, MUF: Memecylon umbellatum fruit 


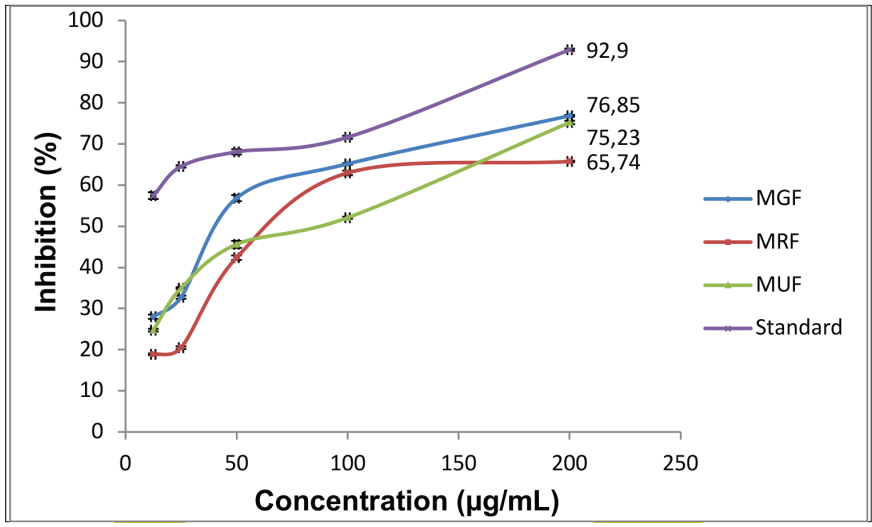

Figure 10. In vitro nitric oxide radical scavenging activity of Memecylon fruits

MGF: Memecylon grande fruit, MRF: Memecylon randerianum fruit, MUF: Memecylon umbellatum fruit

free radical scavenging assays provide an acquaintance of a natural antioxidant source. Therefore, these findings can be effectively targeted toward the pharmacological utilization of Memecylon fruits.

The present investigation focuses on the seed morphology, pharmacognostic, phytochemical, and antioxidant potential of Memecylon fruits. M. grande, M. randerianum and M. umbellatum are the selected experimental plant materials. Powder microscopy, SEM-EDX and ICP-MS analysis were carried out to analyze the surface features and elemental composition of the Memecylon fruits. The antioxidant potential of fruit samples are analyzed by DPPH, hydroxyl, super oxide and nitric oxide radical scavenging assays. The analysis of morphological features are key diagnostic tools in taxonomic studies. In the present study SEM analysis of fruit samples gave valuable results in species identification of Memecylon. The each sample shows distinct surface morohology. In ICP-MS analysis, elemental composition of fruit samples reveals the diverse elemental presence in the sample. It may helpful in pharmaceutical field for valuable medicine preparations. In the four antioxidant assays, all the selected extracts shows promising free radical scavenging activity. So all these results pointing that selected Memecylon fruit samples become a potential contributor in the pharmaceutical field.

\section{ACKNOWLEGEMENTS}

The first author gratefully acknowledges Council of Scientific and Industrial Research, Government of India (09/043(0182)/2017-EMR-I), for the award of fellowship. The author also acknowledges Central Sophisticated Instrumentation Facility, Calicut University for providing SEMEDX, ICP-MS facilities for the research work.

Conflicts of interest: No conflict of interest was declared by the authors. The authors alone are responsible for the content and writing of the paper.

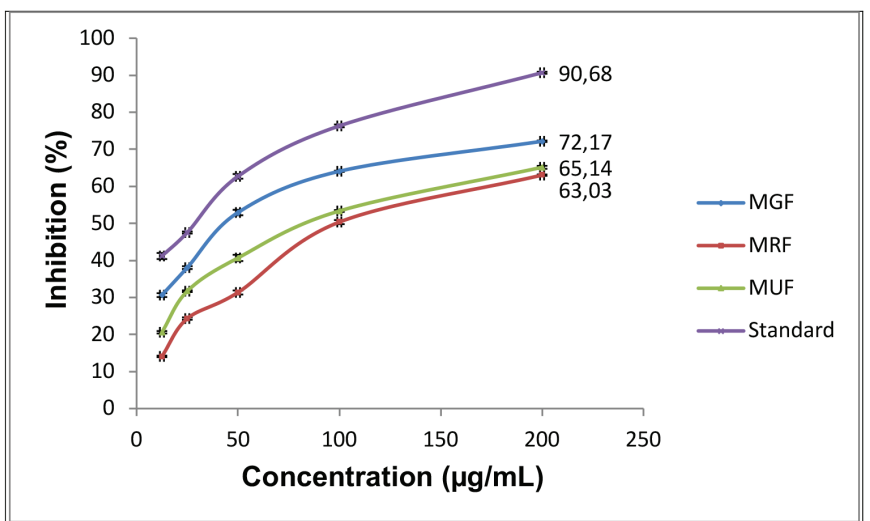

Figure 11. In vitro super oxide radical scavenging activity of Memecylon fruits

MGF: Memecylon grande fruit, MRF: Memecylon randerianum fruit, MUF: Memecylon umbellatum fruit

\section{REFERENCES}

1. Mueller S. Green technology and its effect on the modern world. Bachelor's thesis, Business Information Technology, Oulu University of Applied Sciences. Spring 2017.

2. Sivu AR, Pradeep NS, Ratheeshkumar KB, Pandurangan AG. Evaluation of phytochemical, antioxidant and antimicrobial activities of Memecylon $\mathrm{L}$. species from Western Ghats. Indian J Nat Prod Resour. 2013;4:363-370.

3. Sridevi $H$, Jayaraman P, Pachaiyappan P. Anti-inflammatory and antioxidant activities of Memecylon umbellatum. Burm. leaf extract under in vitro. J Pharm Biol Sci. 2014;4:61-68.

4. Bharathi RT, Sampath Kumara KK, Prakash HS. Memecylon species: a review of traditional information and taxonomic description. Int J Pharm Pharm Sci. 2016;8:1-9.

5. Özcan T. Analysis of the fruit surfaces in Bupleurum L. (Umbelliferae) with SEM. Plant Syst Evol. 2004;247:61-74.

6. Killedar SG, More HN, Nadaf SJ. Microscopic evaluation of leaves of Memecylon umbellatum Burm. Adv Agric. 2014;2014:1-6.

7. Beltrami D, Calestani D, Maffini M, Suman M, Melegari B, Zappettini A, Zanotti L, Casellato U, Careri M, Mangia A. Development of a combined SEM and ICP-MS approach for the qualitative and quantitative analyses of metal nano and microparticles in food products [corrected]. Anal Bioanal Chem. 2011;401:1401-1409. Erratum in: Anal Bioanal Chem. 2011;401:1453.

8. Vaishali Rai M, Pai VR, Pratapchandra Kedilaya H, Hegde S. Preliminary phytochemical screening of members of Lamiaceae family: Leucas linifolia, Coleus aromaticus and Pogestemon patchouli. Int J Pharm Sci Rev Res. 2013;21:131-137.

9. Birben E, Sahiner UM, Sackesen C, Erzurum S, Kalayci O. Oxidative stress and antioxidant defense. World Allergy Organ J. 2012;5:9-19.

10. Shamsa F, Monsef H, Ghamooshi R, Verdian-rizi M. Spectrophotometric determination of total alkaloids in some Iranian medicinal plants. Thai $J$ Pharm Sci. 2008;32:17-20.

11. Chang CC, Yang MH, Wen HM, Chern JC. Estimation of total flavonoid content in propolis by two complementary colorimetric methods. J Food Drug Anal. 2002;10:178-182.

12. Singleton VL, Rossi JA. Colorimetry of total phenolics with phosphomolybdic-phosphotungstic acid reagents. Am J Enol Viticult. 1965;16:144-158. 
13. Ghorai N, Chakraborty S, Gucchait S, Saha SK, Biswas S. Estimation of total terpenoids concentration in plant tissues using a monoterpene, linalool as standard reagent. Protoco Exch. 2012;5.

14. Chang ST, Wu JH, Wang SY, Kang PL, Yang NS, Shyur LF. Antioxidant activity of extracts from Acacia confusa bark and heartwood. J Agric Food Chem. 2001; 49:3420-3424.

15. Kunchandy E, Rao MNA. Oxygen radical scavenging activity of curcumin. Int J Pharm. 1990;58:237-240.

16. Kumaran A, Karunakaran RJ. Nitric oxide radical scavenging active components from Phyllanthus emblica L. Plant Foods Hum Nutr. 2006;61:1-5.

17. Valentão P, Fernandes E, Carvalho F, Andrade PB, Seabra RM, Bastos ML. Hydroxyl radical and hypochlorous acid scavenging activity of small centaury (Centaurium erythraea) infusion. A comparative study with green tea (Camellia sinensis). Phytomedicine. 2003;10:517-522.

18. Degano C, Alonso ME, Ochoa J, Catan A. Seed characterization and scanning electron microscope (SEM) morphology of the testa of three groups of argentine Opuntia ficus-indica (Cactaceae). J Prof Assoc Cactus Dev. 1997;2:103-114.

19. Chen S, Diekmann H, Janz D, Polle A. Quantitative X-ray elemental imaging in plant materials at the subcellular level with a transmission electron microscope: applications and limitations. Materials (Basel). 2014;7:31603175.

20. Padmavathy J, Raju D, Saraswathi VS, Kayalvizhi M, Saravanan, D. Pharmacognostic parameters for the evaluation of the leaves and young stem of Memecylon umbellatum Burm. f. Int J Pharmtech Res. 2010;2:2001-2006.

21. Prashanth L, Kattapagari KK, Chitturi RT, Baddam VRR, Prasad LK. A review on role of essential trace elements in health and disease. J NTR Univ Health Sci. 2015;4:75-85.
22. Watts DL. The nutritional relationships of copper. J Orthomol Med. 1989;4:99-108.

23. Watson TD. Diet and skin disease in dogs and cats. J Nutr. 1998;128:2783S-2789S.

24. Anderson RA. Nutritional factors influencing the glucose/insulin system: chromium. J Am Coll Nutr. 1997;16:404-410.

25. Al-Fartusie FS, Mohssan SN. Essential trace elements and their vital roles in human body. Indian J Adv Chem Sci. 2017;5:127-136.

26. Trace elements in human nutrition. Report of a WHO Expert Committee. Geneva, World Health Organization, 1973 (WHO Technical Report Series, no. 532).

27. Liu RH. Health-promoting components of fruits and vegetables in the diet. Adv Nutr. 2013;4:384S-392S.

28. Kukula-Koch WA, Widelski J. Alkaloids. In: Pharmacognosy. Academic Press. 2017:163-198.

29. Liwa AC, Barton EN, Cole WC, Nwokocha CR. Bioactive plant molecules, sources and mechanism of action in the treatment of cardiovascular disease. In: Pharmacognosy. Academic Press; 2017:315-336.

30. Leung HW, Lin CJ, Hour MJ, Yang WH, Wang MY, Lee HZ. Kaempferol induces apoptosis in human lung non-small carcinoma cells accompanied by an induction of antioxidant enzymes. Food Chem Toxicol. 2007; 45:2005-2013.

31. Tan AC, Konczak I, Sze DM, Ramzan I. Molecular pathways for cancer chemoprevention by dietary phytochemicals. Nutr Cancer. 2011;63:495505.

32. Dudonné $S$, Vitrac $X$, Coutière $P$, Woillez M, Mérillon JM. Comparative study of antioxidant properties and total phenolic content of 30 plant extracts of industrial interest using DPPH, ABTS, FRAP, SOD, and ORAC assays. J Agric Food Chem. 2009;57:1768-1774. 